\title{
The role of far-red light (FR) in photomorphogenesis and its use in greenhouse plant production
}

\author{
Bojka KUMP ${ }^{1,2}$
}

Received May 08, 2020; accepted May 30, 2020.

Delo je prispelo 08. maja 2020, sprejeto 30. maja 2020.

The role of far-red light (FR) in photomorphogenesis and its use in greenhouse plant production

Abstract: Light energy is one of the most important factors regulating the growth and development of plants. In greenhouses and other controlled- environments in which the natural radiation intensities are often low, plant production relies on supplementary lighting to optimize the photosynthesis, increase production levels, and enable year-round production. For a long time, the research related to artificial lighting sources focused on the optimization of the efficiency of use for photosynthesis. The quality of light in plant production has been widely addressed only recently with the development of advanced LED technology that is energy efficient and enables the control of the spectral composition of light. Red and farred light are sensed by the phytochromes that trigger several morphological and developmental processes that impact productivity and yield quality. Thus, to efficiently exploit all the advantages of LEDs and to develop LED arrays for specific plant applications, it is essential to understand thoroughly how light quality influences plant growth and development. This paper presents an overview of the recent developments in light quality manipulation, focusing on far-red light and the R: FR ratio, to improve yield and quality of products and to manage plant architecture and flowering in vegetable and ornamental horticulture.

Key words: far-red light; greenhouse; LEDs, light quality; photomorphogenesis; R: FR ratio
Vloga dolgovalovne rdeče svetlobe $v$ fotomorfogenezi in njena uporaba pri vzgoji rastlin $\mathrm{v}$ rastlinjakih

Izvleček: Svetlobna energija je eden najpomembnejših dejavnikov, ki uravnava rast in razvoj rastlin. V rastlinjakih in ostalih zavarovanih prostorih, kjer je jakost naravnega sevanja velikokrat majhna, je vzgoja rastlin odvisna od dosvetljevanja, ki omogoča optimizacijo fotosinteze, povečanje pridelka in celoletno vzgojo rastlin. Dolgo časa so se raziskave povezane z umetnimi viri osvetljevanja osredotočale predvsem na izboljšanje učinkovitosti za fotosintezo. Vloga kvalitete svetlobe pri rastlinski pridelavi je postala zanimiva šele pred kratkim, z razvojem energetsko učinkovite, napredne LED tehnologije, katere glavna prednost je, da omogoča nadzor nad spektralno sestavo svetlobe. Rdeča in dolgovalovna rdeča svetloba, ki jo rastline zaznavajo s fotoreceptorji fitokromi, sprožita številne morfološke in razvojne procese, ki vplivajo na količino in kvaliteto pridelka. Za dober izkoristek vseh prednosti LED tehnologije in razvoj "LED matrik" za specifično rastlinsko uporabo, je potrebno dobro razumevanje vpliva spektralne sestave svetlobe na rast in razvoj rastlin. V prispevku je predstavljen pregled napredka na področju upravljanja s svetlobo, s povdarkom na dolgovalovni rdeči svetlobi in razmerju med rdečo in dolgovalovno rdečo svetlobo, za povečanje in izboljšanje kakovosti pridelka, ter uravnavanje zgradbe rastlin in cvetenja $\mathrm{v}$ pridelavi vrtnin in okrasnih rastlin.

Ključne besede: dolgovalovna rdeča svetloba; rastlinjak; LED luči; kvaliteta svetlobe; fotomorfogeneza; $\mathrm{R}$ : FR razmerje

1 University of Ljubljana, Biotechnical Faculty, Agronomy Department, Ljubljana, Slovenia

2 Corresponding author, e-mail: bojka.kump@bf.uni-lj.si 


\section{INTRODUCTION}

Many food and ornamental horticultural crops are produced year-round in greenhouses. Recently, plant factories and vertical farms that can ensure a supply of locally produced, fresh food are also being introduced (Bantis et al., 2018). The availability of natural sunlight in these controlled-environments is often limited and could prevent or suppress plant production during large parts of the year. In such circumstances, the production of many crops rely on artificial lighting

In greenhouses, traditional artificial lighting sources, such as fluorescent, high-pressure sodium, metal halide and incandescent lamps, have long been used as a solo source or supplemental lighting to enhance photosynthesis and/or to regulate plant development (Bilodeau et al., 2019; Bantis et al., 2018). The spectral qualities of artificial light sources differ with each other and from natural light. Metal halide and especially high-pressure sodium lamps (HPS) have been usually used to provide high-intensity lighting for plant growth applications.

Recently developed lighting source in the form of light-emitting diodes (LEDs) offers many advantages over conventional artificial lighting sources (Chang et al., 2012; Olle \& Viršile, 2013; Morrow, 2008; Yeh \& Chung, 2009; Singh et al., 2015; Cho et al., 2017; Viršilè et al., 2017). Advantages include high-energy efficiency, long operating lifetime, narrow spectral emissions, adjustable size, etc. (Singh et al., 2015; Nelson \& Bugbee, 2014). LEDs also produce significantly lower leaf temperatures and are thus suitable for low-intensity lighting within the plant canopies (Massa et al., 2005). One of the most valuable properties of LEDs is the ability to control the spectral composition of supplemental lighting, which enables investigating the effects of individual wavelengths or different spectral combinations of wavelengths on plant growth and development. The first commercially available LED fixtures were mainly designed to support photosynthesis and contained mostly red and blue diodes ( $10 \%-25 \%$ blue diodes). To date, many experiments have focused on designing an optimal lighting system, mostly modifying the proportion of different wavelengths within photosynthetically active radiation (PAR) region to support plant growth (Massa et al., 2008) and, more recently, also to precisely regulate plant development. The spectral quality of light affects a great number of plant developmental processes, including germination, seedling establishment, development of rosette, branching and apical dominance, the definition of adult plant architecture, the regulation of flowering, etc. (Franklin \& Quail, 2010; Sánchez-Lamas et al., 2016).

The objective of this review is to present a short overview of the principles of red $(\mathrm{R})(\approx 625-700 \mathrm{~nm})$ and far-red (FR) (> $700 \mathrm{~nm}$ ) light perception by phytochromes and their impact on plant growth and development, which play an essential role in greenhouse plant production. We summarise the research work referring to the use of far-red light or manipulating the $\mathrm{R}$ : FR ratio, to improve yield and quality of products and to manage plant architecture and flowering in vegetable and ornamental horticulture.

\section{RADIATION AND PLANTS}

About $40-50 \%$ of the solar energy received by ecosphere falls in the spectral region of 380-780 nm, which we perceive as visible light. The visible light range includes violet $(\approx 400-450 \mathrm{~nm})$, blue $(\approx 450-520 \mathrm{~nm})$, green $(\approx 520-560 \mathrm{~nm})$, yellow $(\approx 560-600 \mathrm{~nm})$, orange $(\approx 600-625)$, red $(\approx 625-700 \mathrm{~nm})$ and far-red $(>700 \mathrm{~nm})$. On the short-wavelength end of this region is ultraviolet radiation (UV-A, 315-380 nm; UV-B, 280-315 nm; UV-C from artificial sources of radiation, $100-280 \mathrm{~nm}$ ) and, at the other end, there is infrared radiation $(780-3000 \mathrm{~nm})$. The radiation that hits the plant can be reflected at the surface, absorbed or transmitted; the degree of these three events depends on the wavelength of the radiation (Larcher, 1991) and plant organs structure. For a plant, radiation is the energy source and a stimulus regulating development, but it can also cause photo-inhibitory and photo-destructive effects.

In photo-energetic processes, the absorbed energy is used for the photosynthesis or other metabolic reactions or chemical transformations. The action spectrum of plant leaves was described as the span of wavelengths from approximately 400-700 nm, over which plants absorb and effectively use radiant light energy for photosynthesis (McCree, 1972). This photosynthetically active radiation, now commonly known as PAR, is the most important part of the light spectrum for plants; it falls within the visible light range. It relates the intensity and rate of radiant light energy per surface area emitted by a light source from within the action spectrum of plants (Bilodeau et al., 2019). The amount of light that reaches the plant within the PAR region, or the number of photosynthetically active photons that fall on a given surface each second, is measured as a photosynthetic photon flux density (PPFD) and is expressed in $\mu \mathrm{mol} \mathrm{m}^{-2} \mathrm{~s}^{-1}$. The photoreceptors that play an important role in photosynthesis are chlorophylls with absorption maxima in the red and blue, along with antenna pigments that include different carotenoids, such as $\beta$-carotene, zeaxanthin, lycopene, and lutein (Singh et al., 2015).

Plants are also sensitive to other wavelengths, for example, far-red radiation of a wavelength of approxi- 
mately 700-800 nm. It is known that the far-red part of spectrum strongly affects plant development. The regulation of plant growth and development by light signals is termed 'photomorphogenesis'. Recently, it was shown that far-red light could also increase photosynthetic efficiency (Zhen \& van Iersel, 2017).

Plants respond to changes in light, including its intensity, spectral quality, direction and duration through different types of photoreceptors. Not considering chloroplast pigments, to date, five photosensory systems have been identified, (i) the phytochromes (phys) that absorb maximally in the red (600-700 $\mathrm{nm}$ ) and far-red (700$750 \mathrm{~nm}$ ) regions of the spectrum, (ii) the cryptochromes (crys), phototropins (phots) and members of the Zeitlupe family (ztl, fkf1 and lkp2) that absorb the blue light (390-500 nm) and (iii) UV resistance locus 8 (UVR8) that monitors the ultraviolet B wavelengths (280-315 nm) (Bantis et al., 2018).

\section{PHYTOCHROMES}

Phytochromes are light-sensing molecules present in bacteria, cyanobacteria, fungi, algae, and land plants. The first indications of their role in plant development came from studies in the 1930s, although its chemical isolation and identification happened much later (Taiz \& Zeiger, 2014).

Native phytochrome is a soluble protein with a molecular mass of about $250 \mathrm{kDa}$. It occurs as a dimer made up of two equivalent subunits. Each subunit consists of a light-absorbing pigment molecule called the 'chromophore' that is synthesized in chloroplasts and a polypeptide chain called 'apoprotein', synthesized in the cytosol. Together they form the holoprotein, which can absorb light (Taiz \& Zeiger, 2014; Lagarias \& Rapoport, 1980).

Phytochrome exists in two interconvertible forms that differ in their absorption spectra. The inactive $\mathrm{Pr}$ form is synthesized in the dark and after the absorption of red light $(660 \mathrm{~nm})$ changes chemically into the active $\mathrm{Pfr}$ form. Pfr is inactivated by the conversion back to $\mathrm{Pr}$ after the absorption of far-red light $(730 \mathrm{~nm})$ or through thermal relaxation, which depends on temperature. (Taiz \& Zeiger, 2014; Legris et al., 2019). Phytochromes act as dimers and subunits are connected in three possible combinations Pr-Pr, Pfr-Pr, and Pfr-Pfr.

The photo-reversibility is the most distinctive property of phytochrome and results in a dynamic photoequilibrium of Pr and Pfr that depends on light quantity, spectral composition and temperature (Franklin and Quail, 2010; Jung, 2016). The absorption of light by Pr induce an extensive variety of different responses that can be grouped into two types: (i) rapid biochemical events and (ii) slower morphological changes, including movements and growth (Taiz \& Zeiger, 2014).

Phytochrome is encoded by a small multigene family named $P H Y$, the apoprotein without chromophore is designated 'PHY', and the holoprotein is designated 'phy' (Taiz \& Zeiger, 2014). Phytochromes in seed plants diverged into three major forms, phyA, phyB, and phyC, very early in the history of seed plants. In some dicotyledonous species, two additional forms, phyE and phyD, were found and are presumably derived by gene duplication. Each phytochrome has different roles, and their relative contributions vary depending on the environmental conditions and developmental stage of the plant (Legris et al., 2019). PhyA and phyB are present in all sampled angiosperms and are the principal mediators of red/far-red-induced responses.

Research of the expression patterns of the $P H Y$ gene family of products has shown that there are two different classes of phytochromes with distinct properties: light labile Type I and light stable Type II (Tokuhisa et al., 1985; Furuya, 1993). Type I class, represented by phyA, induces very low fluence responses (VLFRs) and far-red high-irradiance responses (FR-HIR). The examples of conditions where phyA is activated are deep shade or few centimetres under the soil surface. Type II phytochromes (phyB-phyE) evoke signals called 'low fluence responses' (LFRs), and these are activated in more open environments (Legris et al., 2019).

Following light perception and conversion to the Pfr form, phytochromes translocate to the nucleus where they selectively interact with several classes of transcription factors and trigger downstream signalling, participating in the regulation of transcription posttranscriptional regulation, and translation (Legris et al., 2019).

In addition to light, phytochromes also contribute to temperature responses with phyB having a major role (Jung et al., 2016; Legris et al., 2019). The molecular mechanisms of photo- and thermo-morphogenesis have mostly been analysed separately, but it is now well recognised that light and temperature signalling are connected (Lorenzo et al., 2016; Patel et al., 2013).

Phytochromes can act synergistically with other photoreceptors. The interaction of phytochrome and cryptochrome signalling and interaction between phytochrome and phototropin photoreceptors have been reported in Arabidopsis (Ahmad et al., 1998; Mas et al., 2000; Parks et al., 1996).

\subsection{PHYTOCHROMES AND R : FR RATIO IN PHO- TOMORPHOGENESIS}

Pr and Pfr forms of phytochromes have overlapping 
absorption spectra and can monitor the $\mathrm{R}$ : FR ratio of light. The $\mathrm{R}$ : FR ratio is usually used to quantify spectral photon flux distribution in the $\mathrm{R}$ and FR wavelengths. The equilibrium between the Pr and Pfr forms dynamically changes with the composition of the light spectrum within the $300-800 \mathrm{~nm}$ range and is strongly correlated with $\mathrm{R}$ to FR proportions of red and far-red light in incident radiation (Holmes \& Smith, 1977). Sunlight at midday has approximately equal amounts of $\mathrm{R}$ and FR resulting in an $\mathrm{R}$ : FR ratio slightly above 1 , but at the beginning and end of the photoperiod it is much lower (about 0.6). The $\mathrm{R}$ : FR ratio slightly varies with cloud covering and is little sensitive to seasonal variation (Turnbull \& Yates, 1993). However, in environments with high plant density, the $\mathrm{R}$ : FR ratio is considerably reduced ( 0.13 under ivy canopy) (Taiz \& Zeiger, 2014). In canopies, the R : FR ratio perceived by plant organs varies spatiotemporally in a range within which slight $\mathrm{R}$ : FR variation causes large variation in phytochrome photo-equilibrium (DemotesMainard et al., 2016).

Phytochromes are potent regulators of plant development and, through the perception of the $\mathrm{R}$ : FR ratio of light, affect a broad range of responses throughout the plant life cycle (Franklin \& Quail, 2010; Sánchez-Lamas et al., 2016). The change in the $\mathrm{R}$ : FR ratio triggers a series of responses in plant vegetative architecture including higher stem length, bud outgrowth, leaf expansion, petiole extension, root development, leaf hyponasty and phototropism, accelerated flowering, etc., known collectively as 'shade avoidance syndrome' (SAS). Green tissues of plants with high chlorophyll content absorb mostly red (R) and blue (B) wavelengths, but let through the FR light, so with shading the $\mathrm{R}$ : FR ratio decreases. The greater proportion of far-red light converts more Pfr to $\mathrm{Pr}$, and the ratio of active Pfr to total phytochrome (Pfr/ $\mathrm{P}_{\text {total }}$ ) decreases.

The shade-avoiding response is characteristic of 'sun plants' and represents a competitive advantage as it enables the plants to acquire more PAR. The sensitivity of plants to low $\mathrm{R}$ : FR ratio can vary during the day (Casal et al., 1997) and it also depends on the variety and species (Casal \& Smith, 1989). The SAS response is weak or not present in 'shade plants', which normally grow in the shade (Taiz \& Zeiger, 2014).

One of the SAS responses triggered by a low $\mathrm{R}$ : FR ratio is a faster transition to flowering. It is common in many plant species, including many agronomical significant ones (Taiz \& Zeiger, 2014). The first step in flowering, the flower induction, is a result of the integration of various environmental and endogenous cues that work through different genetic pathways. The photoperiod pathway is one of them and refers to the regulation of flowering in response to day length and quality of light perceived (Srikanth \& Schmid, 2011). On the basis of the photoperiod, plants can be classed as short-day (SDP) or long-day plants (LDP), although the critical factor in determining their activity is night length. Species that flower under any photoperiodic condition are referred to as 'day-neutral plants' (DNP).

\section{APPLICATIONS OF FAR-RED LIGHT IN GREENHOUSE PLANT PRODUCTION}

There are many areas in crop production, of both food crops and ornamental crops, for which the use of FR light has been shown to have especially promising value. In vegetable horticulture, the two main factors defining yield are biomass production and product quality, inclusive of nutritional value, visual appearance, resistance to 'environmental factors' and others. In growing ornamental plants, the main focuses are their visual appearance and flowering characteristics.

\subsection{PHOTOSYNTHESIS AND BIOMASS PRODUC- TION}

Biomass production is usually directly correlated to photosynthesis, and it depends on the quantity of photosynthetically active radiation received by the leaves. The primary environmental factors that influence crop growth include photosynthetic light intensity and duration per day (which, when integrated formulates the photosynthetic daily light integral), light quality, temperature, and carbon dioxide concentration (Runkle, 2013).

Due to the poor absorption of far-red light $(\lambda>$ $700 \mathrm{~nm}$ ) by leaves and the low quantum yield of photosynthesis, it has long been thought that it makes no or minimal contribution to photosynthesis (McCree, 1972). It is now known that the low quantum yield of photosynthesis under far-red light is caused by unbalanced excitation of the photosystems PSI and PSII, which operate in series to carry out photochemical reactions (Myers, 1971). If shorter wavelength light is supplemented with far-red light that preferentially excites PSI, the excitation balance between the two photosystems can be restored. This can synergistically increase photochemistry and photosynthesis (Zhen \& Van Iersel, 2017).

Zhen and Van Iersel (2017) report that the addition of far-red light to red/blue and warm-white light immediately increased quantum yield of photosystem II $\left(\Phi_{\mathrm{PSII}}\right)$ of lettuce by an average of 6,5 and $3 \%$, respectively. Besides the short-term effect, after $20 \mathrm{~min}$ of exposure to far-red light, an increase of $\Phi_{\text {PSII }}$ and a decrease of nonphotochemical quenching (NPQ) were noted. The in- 
crease of $\Phi_{\text {PSII }}$ was associated with an increase in net photosynthesis. A $7.5 \%$ increase in $\Phi_{\text {PSII }}$ upon adding far-red light $\left(90 \mu \mathrm{mol} \mathrm{m}^{-2} \mathrm{~s}^{-1}\right.$ within $\left.700-770 \mathrm{~nm}\right)$ to a red/blue measuring light $\left(200 \mu \mathrm{mol} \mathrm{m}^{-2} \mathrm{~s}^{-1}\right)$ resulted in an $18 \%$ increase in net photosynthetic rate. In a later study, Zhen et al. (2019) quantified the efficiency of different wavelengths of far-red light exciting PSI by measuring the change in quantum yield of PSII of lettuce grown under red/blue light or under sunlight. The $\Phi_{\text {PSII }}$ of lettuce increased with increasing wavelengths of added light from 678 to $703 \mathrm{~nm}$, indicating longer wavelengths within this region are increasingly used more efficiently by PSI than by PSII. Adding $721 \mathrm{~nm}$ light resulted in similar $\Phi_{\text {PSII }}$ as adding $703 \mathrm{~nm}$ light, but $\Phi_{\text {PSII }}$ tended to decrease as wavelength increased from 721 to $731 \mathrm{~nm}$, likely due to decreasing absorptance and low photon energy. Adding $752 \mathrm{~nm}$ light did not affect $\Phi_{\text {PSII }}$. The beneficial effects of FR light on photosynthesis at fluctuating light was also proved in Arabidopsis by Kono et al. (2020).

Photosynthesis is dependent on the intensity and quality of light that reaches chloroplasts. Yang et al. (2018) studied the interactions between light intensity and the R : FR ratio on the photosynthesis of soybean leaves under shade condition. From the results of quantitative proteomic analysis, they conclude that light intensity directly affects photosynthesis by regulating the expression of photosynthetic proteins and that a low $\mathrm{R}$ : FR ratio could improve the photosynthetic capacity by increasing light-harvesting capacity and stimulating the electron transport of PSI (Yang et al., 2018).

Whole-plant gas exchange measurements of $16 \mathrm{C}_{3}$ and two $\mathrm{C}_{4}$ species under red/blue light and red/blue plus FR light indicated that adding far-red photons $(10-30 \%$ of PPFD) caused similar increases in the whole canopy photosynthetic rate as adding the same amount of red/ blue photons (Zhen \& Bugbee, 2019). To demonstrate that far-red photons are equally efficient at driving photosynthesis, the authors grew lettuce under spectra with or without $15 \%$ of far-red photons at the same total photon flux, and the results at harvest showed $35 \%$ higher dry biomass in treatments with far-red photons, which was almost entirely caused by enhanced radiation capture through leaf expansion.

There is, however, a variability among studies and, in some species, the specific net assimilation rate decreases in response to a low $\mathrm{R}$ : FR ratio or PHYB reduced expression. The different and sometimes contrasted responses between studies may reflect variability between species and genotypes, and/or variability in the growing conditions used (Demotes-Mainard et al., 2016 citations therein).

In addition to its direct effect on photosynthesis, the $\mathrm{R}$ : FR ratio can influence the process also indirec- tly, through its effect on morphological characters, for example, branching, leaf area and leaf orientation (Demotes-Mainard et al., 2016). A higher proportion of FR light, applied to some ornamental plant species has been shown to cause leaf expansion mediated by phytochromes, thus promoting canopy light interception and indirectly increasing plant growth during long-term cultivation (Park \& Runkle, 2017).

Phytochrome B also regulates other traits involved in photosynthesis. It was shown to promote stomatal maturation in Arabidopsis thaliana (Kang et al., 2009), regulate the activity of some enzymes of the Calvin cycle (Bradbeer, 1971) and control the development of chloroplasts (Thiele et al., 1999).

\subsection{FR AND YIELD QUALITY}

The quality of the crop yield is an essential parameter for any grower. Its various aspects rely upon the light intensity and, to a larger extent, on light quality, which is the wavelengths perceived by the plant. With modifications of the light spectrum, the simultaneous increase in biomass and better quality of the product can be obtained. Most recent investigations are thus focused on both characteristics. A large number of studies in vegetable horticulture have been done using lettuce and tomato as a model species.

In a study in which lettuce was grown under cool white fluorescent lamp supplemented with R or FR LED, the plants exposed to FR light demonstrated enhanced fresh and dry mass, stem length, and leaf length and width, but the content of anthocyanin, carotenoid, and chlorophyll was reduced (Li \& Kubota, 2009). Similarly, red leaf lettuce grown under R supplemented with FR light also exhibited lower anthocyanin concentration and antioxidant potential, whereas $\mathrm{R}$ light supplemented with blue (B) light caused the exact opposite results (Stutte et al., 2009).

Zhang et al. (2019a) performed three greenhouse experiments to determine the effects of supplemental lighting with different spectral quality on lettuce growth, colouration, and sensory attributes. Four hours of endof-day (EOD) lighting of low intensity $\left(2-5 \mu \mathrm{mol} \mathrm{m}^{-2} \mathrm{~s}^{-1}\right)$ had only minor effects on lettuce growth and quality attributes, but R + B LED supplemental lighting resulted in darker, redder, and less yellowish plants.

An essential role of FR light for improving the production of indoor cultivated lettuce has been demonstrated in an experiment done by Zou et al. (2019). Adding $50 \mu \mathrm{mol} \mathrm{m}^{-2} \mathrm{~s}^{-1}$ of FR light to $200 \mu \mathrm{mol} \mathrm{m}{ }^{-2} \mathrm{~s}^{-1}$ of $\mathrm{R}+\mathrm{B}$, applied during the day $(16 \mathrm{~h})$ or as EOD $(1 \mathrm{~h})$, resulted in $39 \%$ and $25 \%$ increase in total biomass. Adding FR light 
resulted in 27-49 \% larger plant leaf area with an open plant canopy, which facilitated a better light interception led to higher plant radiation use efficiency (RUE).

Studies of FR effects during the fruiting stage of crops are much less frequent than research in young plants, although the reports, especially in tomato, are now increasing. Apart from plant morphological alterations, changes in the $\mathrm{R}$ : FR ratio also lead to the redistribution of growth and dry matter within the plants, as indicated by an increased shoot/root ratio and soluble sugar levels under radiation with a low $\mathrm{R}$ : FR ratio. Kalaitzoglou et al. (2019) reported that additional FR light applied as continuous and EOD treatment increased total dry mass of tomato plants in the vegetative growth stage, as well as the fruit number per plant, fresh fruit weight per plant and average fruit fresh mass. Similarly, higher total plant dry mass and higher fruit yield in tomato grown under additional FR radiation were reported by Zhang et al. (2019b). In another study on tomatoes, the R and B + FR light treatment increased the production of soluble sugar, increased the dilution by soluble and storage compounds, and water reduction dilution, leading to a strong increase in glucose, fructose and sucrose concentration in the pericarp (Fanwoua et al., 2019). However, neither study provided sufficient insights on how additional FR increases fruit growth in the fruiting stage of the crop, which is a key step in understanding the FR induced yield improvement in fruit crops like tomatoes. Kim et al. (2019) also observed a significant decrease in water content of tomato fruits produced under FR light, together with a pronounced effect of FR light on biomass allocation between vegetative and reproductive structures. Long-term exposure of tomato plants to low R : FR was associated with reductions in leaf area, chlorophyll content, and vegetative shoot biomass fraction, increases in leaf thickness and fruit biomass, and acceleration of flowering and fruiting.

Recently, intra-canopy lighting, a technique that enables more even light distribution within the crop canopy, has been widely applied for high-wire fruit vegetable production in greenhouses. In a study of Zhang et al. (2019b), tomatoes were grown under intra-canopy R and B LEDs supplemented with overhead FR lights in three different duration regimens, (i) 12 hours during the day, (ii) 1.5 hours in the afternoon and (iii) 0.5 hour in the afternoon. The additional FR lighting led to increased stem elongation, higher leaf length: width ratio, increased leaf area, $9 \%-16 \%$ increase in total biomass and slightly lower soluble sugar content. The stimulation of growth and production were similar in all three treatments (Zhang et al., 2019b).

The effects of specific spectral compositions of light on various quality parameters are often species, or even cultivar specific, and should thus be determined for each species and application separately. The recent wide accessibility of LEDs and promising results on the effects of the FR light in some model species, widely opened the research of this topic in many other agronomical important species, like cucumber (Nishimura et al., 2012; Hao et al., 2012; Shibuya et al., 2016) spinach (Akutsu et al., 2017), kale (Meng et al., 2019), squash (Yang et al., 2012), basil (Meng \& Runkle, 2019), etc.

Morphological changes induced by FR light, especially stem elongation, are often undesirable, but in some cases, the promotion of extension growth is essential. Producing seedlings with long hypocotyls is, for example, desired in vegetable grafting. Chia and Kubota (2010) used FR-rich incandescent lamps, without or with filters that reduced transmission of $\mathrm{R}$ light, to promote elongation of tomato seedlings. They obtained a $20 \%$ increase in hypocotyl length under the $\mathrm{R}$ : FR ratio of 0.47 and $44 \%$ at $\mathrm{R}$ : FR of 0.05 . They concluded that only 2 to $4 \mathrm{mmol} \mathrm{m}^{-2} \mathrm{~d}^{-1}$ of FR light was needed to nearly saturate the promotion of elongation growth. There were no negative effects on dry mass, stem diameter, and plastochron index. The effectiveness of EOD FR lighting from a movable LED fixture on interspecific squash (Cucurbita maxima Duch. $x$ Cucurbita moschata Duch. ex Poir) rootstock hypocotyl elongation was investigated by Yang et al. (2012). The extent of hypocotyl elongation under movable or stationary FR LED fixtures was statistically the same and was 55-69 \% greater than non-treated control (Yang et al., 2012).

It is known that, in addition to a low $\mathrm{R}$ : FR ratio, shade avoidance responses are also regulated by the photosynthetic photon flux density (PPFD). In general, increasing PPFD decreases the magnitude of plant responses to the R : FR ratio. Growing sunflower (Helianthus annuus L.) seedlings at low $\mathrm{R}$ : FR ratio (0.85) at low and moderate PPFD (157 and $421 \mu \mathrm{mol} \mathrm{m}^{-2} \mathrm{~s}^{-1}$ ) resulted in increased growth, but the growth response was attenuated under the higher PPFD (Kurepin et al., 2007). Yang et al. (2018) studied the effects of interactions between light intensity and $\mathrm{R}$ : FR ratio on the photosynthesis of soybean leaves under shade condition. The iTRAQ technique was utilized to analyse differentially expressed proteins involved in photosynthesis, and the results showed that low R : FR could improve the photosynthetic capacity of plants under shade conditions.

Light is also a critical environmental factor for the production of secondary metabolites in plants (Kopsell \& Sams, 2013). It is known that phytochemicals play a significant role in delaying or inhibiting oxidative damage caused by free radicals. Spectral quality has a pronounced effect on accumulating secondary plant metabolites in controlled environment agriculture (Alrifai et 
al., 2019). The studies about the impact of FR light on the phytochemicals content are limited. As mentioned above, lettuce plants exposed to FR light demonstrated enhanced fresh and dry mass, stem length, and leaf length and width, but the content of anthocyanin, carotenoid, and chlorophyll was reduced (Li \& Kubota, 2009); similarly, red leaf lettuce grown under R light supplemented with FR light also exhibited lower anthocyanin concentration and antioxidant potential (Stutte et al., 2009). In such cases, the benefits of adding FR light for increased biomass are tentative. In many studies, FR light was applied together with $\mathrm{B}$ and $\mathrm{R}$ light, and the overall effect of this light combination on secondary metabolites concentration was mostly stimulatory, while the contribution of FR alone was not evaluated (Alrifai et al., 2019). This effect could be explained by enhanced photosynthesis and, consequently, higher metabolism.

Light spectral quality can greatly affect the efficiency of the uptake of resources (water and nutrients) from the soil and affect the way of the plants to adjust the competition for soil resources (Sadras et al., 1989; Gundel et al., 2014). It was shown that the R: FR ratio affects different steps of plant nutrition that are critical for enhanced and sustainable crop production. It can affect root structure (De Simone et al., 2000; Gundel et al., 2014) or root growth (Klem et al., 2019). The establishment of a nitrogen-fixing symbiosis between legumes and rhizobia requires not only sufficient primary metabolites but also the sensing of the $\mathrm{R}$ : FR ratio (Suzuki et al., 2011). R: FR sensing also influences the arbuscular mycorrhizal (AM) symbiosis of a legume and non-legume through jasmonic acid and strigolactone signalling (Nagata et al., 2015). In hydroponically grown lettuce, far-red light stimulated uptake of $\mathrm{N}$ and $\mathrm{K}, \mathrm{Ca}$ and $\mathrm{Mg}$ with the latter increasing by $27 \%, 25 \%$, and $28 \%$, respectively, compared to plants grown under R and B light (Pinho et al., 2017).

Postharvest technology is another field in which the use of LED technology emerged as an efficient lighting source and its use, including FR light, can affect the nutritional and organoleptic parameters of vegetable plants and can be used to delay the senescence of green vegetables ( $\mathrm{Fa}$ vre et al., 2018). The use of $\mathrm{R}$ light or light with high $\mathrm{R}$ : FR ratio has been shown to be the most effective in delaying senescence in broccoli (Favre et al., 2018). Similarly, tomato fruits exposed to LED light with a high $\mathrm{R}$ : FR ratio had increased firmness and higher titratable acidity compared to other darkness exposure or other LED lighting conditions (Nájera et al., 2018).

\subsection{FR IN ORNAMENTAL HORTICULTURE (FLORI- CULTURE)}

In growing ornamental plants, one of the essential points to consider is the shape of plants, of which stem elongation and branching are regarded as very important. Another vital component is flowering, including flowering time and duration, and the number of floral buds. All of these contribute to the plant's visual appearance and therefore to its economic value.

The control of height and branching of many ornamental plants represents a major challenge in commercial greenhouse production. Extremely tall and branched out pot plants are prone to breakage and increase production costs. Usually, in the production of ornamentals, stem growth promotion is not desired, with some exceptions, such as the cultivation of cut flowers (Zhang \& Runkle, 2019). Chemical agents, such as plant growth retardants or gibberellic acid, are commonly used to regulate stem length; however, due to the potential negative effects of plant growth retardants on human health and the environment, limitation of their use is desirable (Rajapakse et al., 1999).

The development of plant vegetative architecture, including stem elongation and branching, is regulated mostly by phytochromes, although the participation of cryptochromes in inhibition of stem elongation has been documented (Liscum et al., 1992). Most plants show some degree of shade-avoidance response in an attempt to reach more photosynthetic light. Generally, under a reduced R : FR ratio, plants elongate. For example, in Digitalis purpurea' Dalmatian Peach' seedlings, the addition of 7.9 to 68.8 $\mu \mathrm{mol} \mathrm{m} \mathrm{m}^{-2} \mathrm{~s}^{-1} \mathrm{FR}$ light to white light ended in a $38 \%$ increase in shoot length in a dose-dependent manner (Elkins et al., 2019).

EOD lighting has been widely used recently to regulate extension growth by manipulating the $\mathrm{R}$ : FR ratio (Downs \& Thomas, 1982; Islam et al., 2015; Ilias \& Rajapakse, 2005). For example, Islam et al. (2014) exposed two poinsettia cultivars to R or FR EOD lighting for $30 \mathrm{~min}$ at $10 \mu \mathrm{mol} \mathrm{m} \mathrm{s}^{-2}$ after a 10-hour short day (SD). After 11 weeks, the internode length was $55 \%$ to $107 \%$ greater under EOD-FR compared with EOD-R.

Many studies illustrate the variability in species responses to light quality and underscore the complexity of how light regulates stem extension and (flowering) in plants (Craig \& Runkle, 2013). Variation in plant height was found in two poinsettia (Euphorbia pulcherrima Willd. ex Klotzsch) cultivars under the 2-h EOD lighting treatments, regardless of light quality. The effect was attributed to different cultivar specificity (Zhang \& Runkle, 2019) and the results were in accordance with the findings of Rajapakse et al. (1993) (cited by Zhang \& Runkle, 2019) who reports that same EOD-FR treatment increased height in one chrysanthemum cultivar by $\approx 50 \%$ while the plant height of the other cultivar was similar to control. Different sensitivity to the $\mathrm{R}$ : FR ratio in stem elongation was observed between three SDP species (Chrysanthemum x morifo- 
lium (Ramat.) Hemsl.), Dahlia x hortensis A. Guillaumin, and Tagetes erecta L.) (Craig \& Runkle, 2013), as well as between five LDP species (Campanula carpatica Jacq., Coreopsis $\times$ grandiflora Hogg ex Sweet, Lobelia $\times$ speciosa Sweet, Pisum sativum L., and Viola $\times$ wittrockiana Gams) (Runkle \& Heins, 2001). In the latter study, reaction to lower R : FR ratio was greater in the sun-adapted species C. carpatica and Platycodon grandiflorus (Jacq.) A.DC. The extension growth was promoted in all five species under B-deficient environment. Based on the results, the authors suggested that blue light plays an important role in mediating stem extension in LDP. Similar conclusions were drawn from the study of petunia (Petunia $x$ hybrida hort. ex E.Vilm.,), geranium (Pelargonium $x$ hortorum L.H.Bailey) and coleus (Solenostemon scutellaroides (L.) Codd) seedlings grown under different combinations of $\mathrm{R}, \mathrm{FR}$, and $\mathrm{B}$ light at various intensities in a 16-hour photoperiod. The height of the plants increased linearly with lowering $\mathrm{R}$ : FR ratio and moderately high $\mathrm{B}$ light attenuated the effects of the $\mathrm{R}$ : FR ratio on extension growth (Park \& Runkle, 2019).

For plants marketed for their flowers, the most crucial point is coordinated control of time and duration of flowering. One of the strategies to manage flowering without using chemicals is light quality manipulation, particularly the $\mathrm{R}$ : FR ratio. Low-intensity photoperiodic lighting is usually used by horticulturists to alter the natural photoperiod to manipulate flowering. The EOD lighting of different duration has been used to extend the natural photoperiod and create long days; recently, the feasibility of adjusting spectral quality of EOD supplemental lighting has broadened the range of possible applications. Another favourable approach of lighting, used for flowering control, is the use of night interruption (NI) lighting, using the light of differing spectral quality. The advantage of short-term lighting is its economic feasibility as a result of its lower intensity requirements and shorter application duration (Chia \& Kubota, 2010).

Photoperiodic flowering in plants is achieved by the interactions of genes involved in the developmental control of floral initiation, the regulation of the circadian clock, and the signal transduction of phytochromes and cryptochromes receptors. For successful planning of flowering, coordination of all environmental factors, including light quality and intensity, timing, temperature, etc., has to be considered.

In SDP, it is acknowledged that R light is most effective at inhibiting flowering (Craig \& Runkle, 2013), but the sensitivity to the $\mathrm{R}$ : FR ratio and the duration of NI or EOD lighting differs between species or even cultivars.

In three SDP ornamental species chrysanthemum, dahlia , and African marigold flowering was delayed at R : FR 0.66 or greater. NI treatment that primarily emits
$\mathrm{R}$ light was determined to be the most effective in terms of flower inhibition for the SDP studied. The comparison between incandescent lights that emit low levels of B light and LED lighting without B light were shown to have similar effects on flowering, and it was found that B light, not FR light alone, was not needed to regulate flowering (Craig \& Runkle, 2013).

In LDP, flowering is promoted most when artificial lighting contains $\mathrm{R}$ and FR light, creating a moderately low Pfr/Pt, compared to light deficient in FR (high Pfr/ $\mathrm{Pt}$ ) (Runkle \& Heins, 2001). To determine the effect of $\mathrm{FR}, \mathrm{R}$, and B light on flowering in five LDP species (Campanula carpatica Jacq., Coreopsis $\times$ grandiflora Hogg ex Sweet, Lobelia $\times$ speciosa Sweet, Pisum sativum L., and Viola $\times$ wittrockiana Gams), plants were exposed to 16 hour photoperiod under R-, FR- and B-deficient photoselective filters in addition to a control (no filter). FR light promoted flowering, although the analysed species showed different sensitivity to changed $\mathrm{R}$ : FR ratios. Reaction to lower $\mathrm{R}$ : FR ratio was, similarly as in stem elongation, greater in sun-adapted species $C$. carpatica and C. $x$ grandiflora. The authors observed that the time of day when the plants are exposed to FR could also have an impact on flowering. In this study, B light had little or no effect on flowering, but since the absorption of $\mathrm{B}$ light has been shown to accelerate flowering in Arabidopsis and Hyoscyamus, the authors speculated that the intensity of B light was to low to induce the effect. The promotion of flowering by 7-11 days at low $\mathrm{R}$ : FR ratio was also observed in LDP petunia (Park \& Runkle, 2019). As in previously cited studies, authors found that B light had no effect on on the FR light promotion of flowering.

Zahedi and Sarikhani (2016) studied the simultaneous effects of EOD FR treatment duration, temperature, and plant age on strawberry (Fragaria $x$ ananassa Duchesne) development. They demonstrated their synergistic effect on the morphological traits and flower induction.

\subsection{FR IN PLANT DEFENCE AND INTERACTIONS WITH ABIOTIC FACTORS}

A vast number of studies has revealed the importance of phytochromes in plant development, although more recently, the evidence of their role in modulating different biotic and abiotic stresses is expanding. The understanding of the molecular mechanisms underlying the reactions controlled by phytochrome is constantly increasing. This and the availability of phytochrome mutants in different plant species facilitates further investigation of their role in the complex coordination of responses to various environmental factors. The propor- 
tion of R and FR light detected by phytochromes, especially phy $\mathrm{B}$, has been shown to play a role in regulating signalling induced by herbivory (Ballaré, 2017), salt stress (Cao et al., 2018), drought stress (González et al., 2012) and temperature change (Lorenzo et al., 2016). Because those environmental conditions can greatly affect plant productivity, the studies on phytochrome regulation of stress responses have become a hot spot of research.

To survive and prosper in different natural conditions, plants must precisely allocate their limited resources between growth and defence. In an environment with low $\mathrm{R}$ : FR ratios (shade) the numerous shade avoidance responses are triggered; however, the plant's immunity is reduced (McGuire \& Agrawal, 2005; Roberts et al., 2006). The main mechanism underlying defence suppression is the simultaneous downregulation of jasmonate and salicylic acid signalling by low ratios of $\mathrm{R}$ : FR radiation (De Wit et al., 2013; Ballaré, 2014). Exposure to a low R : FR light reduced plant resistance against Botrytis cinerea Pers. in Arabidopsis thaliana (L.) Heynh., (Cerrudo et al., 2012; Cargnel et al., 2014) and in tomatoes (Ji et al., 2019). It was shown that fluorescent illumination with a high $\mathrm{R}$ : FR ratio (7.0) in comparison with low $\mathrm{R}$ : FR ratio (1.1) improved the resistance of cucumber seedlings to powdery mildew (Shibuya et al., 2011).

Several studies demonstrated that phytochromes, especially phyB, play a role in modulating signalling induced by drought stress. Drought tolerance can be promoted or depressed, according to species (Demotes-Mainard, 2016). Gonzalez et al. (2012) evaluated how phyB modulates drought-tolerance response by comparing wild-type Arabidopsis thaliana adult plants to the null phy $B$ mutant in response to water shortage. They proposed that phyB, according to changes in the $\mathrm{R}$ : FR ratio, increases drought tolerance by enhancing ABA sensitivity. Drought tolerance could also be affected by morphological responses to the $\mathrm{R}$ : FR ratio, such as changes in leaf area and hyponasty (Demotes-Mainard et al., 2016).

Recently, it has been shown that exposure to lower $\mathrm{R}$ : FR ratios improve tomato tolerance to salt stress most likely through regulation of antioxidant enzymes and non-enzymatic systems and that phytochrome B1 plays a very important role in this process. The improved salt stress tolerance was accompanied by a higher actual quantum yield of photosynthesis (ФPSII), electron transport rate (ETR), and photochemical quenching (qP), indicating overall healthier growth (Cao et al., 2018).

\section{CONCLUSION}

The growing knowledge about photoreceptors and the mechanisms by which light controls plant growth and development have been successfully applied in horticulture. In recent years, light-emitting diodes (LEDs) have facilitated the control of the spectral composition of supplemental lighting and expanded the application of different solo or combined wavelengths in greenhouse plant production. Adding FR light or lowering R : FR ratio has been shown to positively affect the photosynthesis and resulting biomass of some vegetable species. FR light can simultaneously elicit different morphological and physiological responses, among which only some are desirable. To efficiently use lighting for the manipulation of desired characteristics and to provide the horticultural products of high quality, more research is needed to understand better the mutual influence of different spectral combinations of light and other environmental conditions present at cultivation (e.g., photoperiod, temperature, water availability, nutrition, etc.). In many cases, it has been shown that the photomorphogenic responses are species-specific and, since the majority of research is done on a few model species, the analyses of other species would be necessary.

\section{REFERENCES}

Ahmad, M., Jarillo, J.A., Smirnova, O., \& Cashmore, A.R. (1998). The CRY1 blue light photoreceptor of Arabidopsis interacts with phytochrome A in vitro. Molecular Cell, 1, 939-948. https://doi.org/10.1016/s1097-2765(00)80094-5

Akutsu, M., Izena, J., \& Takakura, T. (2017). Effect of EODFR Treatment on the growth and morphology of Japanese Mustard Spinach and Pak-choi. Horticultural Research (Japan), 16(4), 449-454. https://doi.org/10.2503/hrj.16.449

Alrifai, O., Hao, X., Marcone, M.F., \& Tsao, R. (2019). Current review of the modulatory effects of LED lights on photosynthesis of secondary metabolites and future perspectives of microgreen vegetables. Journal of Agricultural and Food Chemistry, 67, 6075-6090. http://dx.doi.org/10.1021/acs. jafc.9b00819

Ballaré, C. L. (2017). Phytochrome Responses: Think Globally, Act Locally. Trends in Plant Science, 22(11), 909-911. https://doi.org/10.1016/j.tplants.2017.09.004

Ballaré, C.L. (2014). Light regulation of plant defense. Annual Review of Plant Biology, 65, 335-363. https://doi. org/10.1146/annurev-arplant-050213-040145

Bantis, F., Smirnakou, S., Ouzounis, T., Koukounaras, A., Ntagkas, N., \& Radoglou, K. (2018). Current status and recent achievements in the field of horticulture with the use of light-emitting diodes (LEDs). Scientia Horticulturae, 235, 437-451. https://doi.org/10.1016/j.scienta.2018.02.058

Bilodeau, S.E., Wu, B., Rufyikiri, A., MacPherson, S., \& Lefsrud, M. (2019). An update on plant photobiology and implications for Cannabis production. Frontiers in Plant Science, 10, 296. https://doi.org/10.3389/fpls.2019.00296

Bradbeer, J.W. (1971). Plastid Development in Primary Leaves of Phaseolus vulgaris: the effect of short blue, red, far-red, 
and white light treatments on dark-grown plants. Journal of Experimental Botany, 22(2), 382-390. https://doi. org/10.1093/jxb/22.2.382

Cao, K., Yu, J., Xu, D., Ai, K., Bao, E., \& Zou, Z. (2018). Exposure to lower red to far-red light ratios improve tomato tolerance to salt stress. BMC Plant Biology, 18, 92. https:// doi.org/10.1186/s12870-018-1310-9

Cargnel, M.D., Demkura, P.V., \& Ballaré, C.L. (2014). Linking phytochrome to plant im-munity: low red: far-red ratios increase Arabidopsis susceptibility to Botrytis cinerea by reducing the biosynthesis of indolic glucosinolates and camalexin. New Phytologist, 204, 342-354. https://doi. org/10.1111/nph.13032

Casal, J.J., \& Smith, H. (1989). The function, action and adaptive significance of phytochrome in light-grown plants. Plant, Cell \& Environment, 12, 855-862. https://doi. org/10.1111/j.1365-3040.1989.tb01966.x

Casal, J.J., Sanchez, R.A., \& Yanovsky, M.J. (1997). The function of phytochrome A. Plant, Cell \& Environment, 20(6), 313819. https://doi.org/10.1046/j.1365-3040.1997.d01-113.x

Cerrudo, I., Keller, M.M., Cargnel, M.D., et al. (2012). Low red/ far-red ratios reduce Arabidopsis resistance to Botrytis cinerea and jasmonate responses via a COI1-JAZ10-dependent, salicylic acid-independent mechanism. Plant Physiology, 158, 2042-2052. https://doi.org/10.1104/pp.112.193359

Chang, M.-H., Das, D., Varde, P., \& Pecht, M. (2012). Light emitting diodes reliability review. Microelectronics Reliability, 52, 762-782. https://doi.org/10.1016/j.microrel.2011.07.063

Chia, P., \& Kubota, C. (2010). End-of-day far-red light quality and dose requirements for tomato rootstock hypocotyl elongation. HortScience, 45(19), 1501-1506. https://doi. org/10.21273/HORTSCI.45.10.1501

Cho, J., Park, J. H., Kim, J. K., \& Schubert, E. F. (2017). White light-emitting diodes: history, progress, and future. Laser \& Photonics Reviews, 11, 1600147. https://doi.org/10.1002/ lpor.201600147

Craig, D.S., \& Runkle, E.S. (2013). A Moderate to high red to far-red light ratio from light-emitting diodes controls flowering of short-day plants. Journal of the American Socety for Horticultural Science, 13(3), 167-172. https://doi. org/10.21273/JASHS.138.3.167

De Simone, S., Oka, Y., Inoue, Y., Nishioka, N., Tadano, S., \& Inoue, Y. (2000). Evidence of phytochrome mediation in the low-pH-induced root hair formation process in lettuce (Lactuca sativa L. cv. Grand Rapids) seedlings. Journal of Plant Research, 113, 45-53. https://doi.org/10.1007/ PL00013915

De Wit, M., Spoel, S.H., Sanchez-Perez, G.F., et al. (2013). Perception of low red: far-red ratio compromises both salicylic acid- and jasmonic acid-dependent pathogen de-fences in Arabidopsis. The Plant Journal, 75, 90-103. https://doi. org/10.1111/tpj.12203

Demotes-Mainard, S., Péron, T., Corot, A. et al. (2016). Plant responses to red and far-red lights, applications in horticulture. Environmental and Experimental Botany, 121, 4-21. https://doi.org/10.1016/j.envexpbot.2015.05.010

Downs, R.J., \& Thomas, J.F. (1982) Phytochrome regulation of flowering in the long-day plant, Hyoscyamus niger.
Plant Physiology, 70(3), 898-900. https://doi.org/10.1104/ pp.70.3.898

Elkins, C.A., Martin, M., \& van Iersel, M.W. (2019). Growth and morphological responsesof Digitalis and Rudbeckia seedlings to supplemental far-red LED light. HortScience, 54(9) Supplement, S89.

Fanwoua, J., Vercambre, G., Buck-Sorlin, G., Dieleman, J.A., de Visser, P., \& Génard, P. (2019). Supplemental LED lighting affects the dynamics of tomato fruit growth and composition. Scientia Horticulturae, 256, 109402. https://doi. org/10.1016/j.scienta.2019.108571

Favre, N., Bárcena, A., Bahima, J.V., Martinez, G., \& Costa., L. (2018). Pulses of low intensity light as promising technology to delay postharvest senescence of broccoli. Postharvest Biology and Technology, 142, 107-114. http://dx.doi. org/10.1016/j.postharvbio.2018.01.009

Franklin, K.A., \& Quail, P.H. (2010). Phytochrome functions in Arabidopsis development. Journal of Experimental Botany, 61(1), 11-24. https://doi.org/10.1093/jxb/erp304

Furuya, M. (1993). Phytochromes: their molecular species, gene families and functions. Annual Review of Plant Physiology and Plant Molecular Biology, 44, 617-645. https://doi. org/10.1146/annurev.pp.44.060193.003153

González, C.V., Ibbara, S.E., Piccoli, P.N., Botto, J.F., \& Boccalandro H.E. (2012). Phytochrome B increases drought tolerance by enhancing ABA sensitivity in Arabidopsis thaliana. Plant, Cell \& Environment, 35, 1958-1968. https://doi. org/10.1111/j.1365-3040.2012.02529.x

Gundel, P. E., Pierik, R., Mommer, L., \& Ballaré, C. L. (2014). Competing neighbors: light perception and root function. Oecologia, 176, 1-10. https://doi.org/10.1007/s00442-0142983-X

Hao, X., Zheng, J., Little, C., \& Khosla S. (2012). Led inter-lighting in year-round greenhouse mini-cucumber production. Acta Horticulturae, 956, 335-340. https://doi.org/10.17660/ ActaHortic.2012.956.38

Holmes, M.G., \& Smith, H. (1977). Function of phytochrome in natural environment 1 , Characterization of daylight for studies in photomorphogenesis and photoperiodism. Photochemistry and Photobiology, 25, 533-538. https://doi. org/10.1111/j.1751-1097.1977.tb09124.x

Ilias, I.F., \& Rajapakse, N. (2005). The effects of end-of-the-day red and far-red light on growth and flowering of Petunia $x$ hybrida 'Countdown Burgundy' grown under photoselective films. HortScience, 40(1), 131-133. http://pascalfrancis.inist.fr/vibad/index.php?action=getRecordDetail\&i $\mathrm{dt}=16437346$

Islam, M.A., Gislerod, H.R., Torre, S., \& Olsen, J.E. (2015). Control of shoot elongation and hormone physiologyin poinsettia by light quality provided by light emitting diodes - a minireview. Acta Horticulturae, 1104, 131-136. https:// doi.org/10.17660/ActaHortic.2015.1104.20

Islam, M.A., Tarkowska, D., Clarke, J.L., Blystad, D.R., Gislerod, H.R., Torre, S., \& Olsen, J.E. (2014). Impact of end-of-day red and far-red light on plant morphology and hormone physiology of poinsettia. Scientia Horticulturae, 174, 77-86. https://doi.org/10.1016/j.scienta.2014.05.013

Ji, Y., Ouzounis, T., Courbier, S. et al. (2019). Far-red radiation increases dry mass partitioning to fruits but reduces Bot- 
rytis cinerea resistance in tomato. Environmental and Experimental Botany, 168, 103889. https://doi.org/10.1016/j. envexpbot.2019.103889

Jung, J.H. (2016). Phytochromes function as thermosensors in Arabidopsis. Science, 354, 886-889. https://doi.org/10.1126/ science.aaf6005

Kalaitzoglou, P., van Ieperen, W., Harbinson, J., van der Meer, M., Martinakos, S., Weerheim, K., Nicole, C.C.S., \& Marcelis, F.M. (2019). Effects of continuos or end-of-day far-red light on tomato plant growth, morphology, light absorbtion, and fruit production. Frontiers in Plant Science, 10, 322. https://doi.org/10.3389/fpls.2019.00322

Kang, C., Lian, H., Wang, F., Huang, J., \& Yang, H. (2009). Cryptochromes, Phytochromes, and COP1 Regulate Light-Controlled Stomatal Development in Arabidopsis. Plant Cell, 21, 2624-2641. https://doi.org/10.1105/tpc.109.069765

Kim, H., Lin, M., \& Mitchell, C.A. (2019). Light spectral and thermal properties govern biomass allocation in tomato through morphological and physiological changes. Environmental and Experimental Botany, 157, 228-240. https:// doi.org/10.1016/j.envexpbot.2018.10.019

Klem, K., Gargallo-Garriga A., Rattanapichai, W., Oravec, M., Holub, P., Veselá, B., Sardans, J., Peñuelas, J., \& Urban, O. (2019). Distinct morphological, physiological, and biological responses ti light quality in barley leaves and roots. Frontiers in Plant Science, 10(1026), 1-18. https://doi. org/10.3389/fpls.2019.01026

Kono, M., Kawaguchi, H., Mizusawa, N.,Yamori, W., Suzuki , Y., \& Terashima, I. (2020). Far-Red Light Accelerates Photosynthesis in the Low-Light Phases of Fluctuating Light. Plant and Cell Physiology, 61(1), 192-202. https://doi. org/10.1093/pcp/pcz191

Kopsell, D.A., \& Sams, C.E. (2013). Increases in shoot tissue pigments, glucosinolates, and mineral elements in sprouting broccoli after exposure to short-duration blue light from light emitting diodes. Journal of the American Socety for Horticultural Science, 138, 31-37. https://doi.org/10.21273/ JASHS.138.1.31

Kurepin, L.V. Emery, R.J., Pharis, R.P., \& Reid, D.M. (2007). Uncoupling light quality from light irradiance effects in $\mathrm{He}$ lianthus annuus shoots. Putative roles for plant hormones in leaf and internode growth. Journal of Experimental Bota$n y$, 58, 2145-2157. https://doi.org/10.1093/jxb/erm068

Lagarias, J.C., \& Rapoport, H. (1980). Chromopeptides from phytochrome: the structure and linkage of the Pfr form of the phytochrome chromophore. Journal of the American Chemical Society, 102, 4821-4828. https://doi.org/10.1021/ ja00534a042

Larcher, W. (2003). Physiological plant ecology. Berlin Heidelberg: Springer-Verlag.

Legris, M., Ince, Y.Ç., \& Fankhauser, C. (2019). Molecular mechanisms underlying phytochrome-controlled morphogenesis in plants. Nature Communications, 10, 5219. https:// doi.org/10.1038/s41467-019-13045-0

Li, Q., \& Kubota, C. (2009). Effects of supplemental light quality on growth and phytochemicals of baby leaf lettuce. Environmental and Experimental Botany, 67, 59- 64. https://doi. org/10.1016/j.envexpbot.2009.06.011

Liscum, E.; Young, J.C.; Poff, K.L., \& Hangarter, R.P. (1992).
Genetic separation of phototropism ad blue light inhibition of stem elongation. Plant Physiology, 100, 267-271. https:// dx.doi.org/10.1104\%2Fpp.100.1.267

Lorenzo, C.D., Sanchez-Lamas, M., Antonietti, M.S., \& Cerdan, P.D. (2016). Emerging hubs in plant light and temperature signaling. Photochemistry and Photobiology 92, 3-13. https://doi.org/10.1111/php.12535

Más, P., Devlin, P.F., Panda, S., \& Kay, S.A. (2000). Functional interaction of phytochrome B and cryptochrome 2. Nature, 408, 207-211. https://doi.org/10.1038/35041583

Massa, G. D., Emmerich, J. C., Mick, M. E., Kennedy, R., Morrow, R. C., \& Mitchell, C. A. (2005). Development and testing of an efficient LED intracanopy lighting design for minimizing Equivalent System Mass in an advanced lifesupport system. Gravitational and Space Biology Bulletin, 18, 87-88. http://gravitationalandspacebiology.org/index. php/journal/article/viewFile/351/354

Massa, G.D., Kim, H.-H., Wheeler, R.M., \& Mitchell, C.A. (2008). Plant productivity in response to LED lighting. HortScience, 43, 1951-1956. https://doi.org/10.21273/ HORTSCI.43.7.1951

McCree, K.J. (1972). The action spectrum, absorptance and quantum yield of photosynthesis in crop plants. Agricultural Meteorology, 9, 191-216. https://doi.org/10.1016/00021571(71)90022-7

McGuire, R., \& Agrawal, A.A. (2005). Trade-offs between the shade-avoidance response and plant resistance to herbivores? Tests with mutant Cucumis sativus. Functional Ecology, 19, 1025-1031. https://doi.org/10.1111/j.13652435.2005.01047.x

Meng, Q., \& Runkle, E.S. (2019). Far-red radiation interacts with relative and absolute blue and red photon flux densities to regulate growth, morphology, and pigmentation of lettuce and basil seedlings. Scientia Horticulturae, 255, 269280. https://doi.org/10.1016/j.scienta.2019.05.030

Meng, Q., Kelly, N., \& Runkle, E.S. (2019). Substituting green or far-red radiation for blue radiation induces shade avoidance and promotes growth in lettuce and kale. Environmental and Experimental Botany, 162, 383-391. https://doi. org/10.1016/j.envexpbot.2019.03.016

Morrow, R.C. (2008). LED lighting in horticulture. HortScience, 43, 1947-1950.

Myers, J. (1971). Enhancement studies in photosynthesis. Annual Review of Plant Physiology, 22, 289-312. https://doi. org/10.1146/annurev.pp.22.060171.001445

Nagata, M., Yamamoto, N., Shigeyama, T. et al. (2015). Red/ far red light controls arbuscular mycorrhizal colonization via jasmonic acid and strigolactone signalling. Plant and Cell Physiology, 56(11), 2100-2109. https://doi.org/10.1093/ pcp/pcv135

Nájera, C., Guil-Guerrero, J.L., Enriquez, L.J., \& Álvaro, J.E. (2018). LED-enhanced dietary and organoleptic qualities in postharvest tomato fruit. Postharvest Biology and Technology, 145, 151-156. https://doi.org/10.1016/j.postharvbio.2018.07.008

Nelson, J. A., \& Bugbee, B. (2014). Economic analysis of greenhouse lighting: light emitting diodes vs. high intensity discharge fixtures. PLOS ONE, 9(6), e99010. https://doi. org/10.1371/journal.pone.0099010 
Nishimura, Y., Wada, E., Fukumoto, Y., Aruga, H., \& Shimoi, Y. (2012). The effect of spectrum conversion covering film on cucumber in soilless culture. Acta Horticulturae, 956, 481487. https://doi.org/10.17660/ActaHortic.2012.956.56

Olle, M., \& Viršile, A. (2013). The effects of light-emitting diode lighting on greenhouse plant growth and quality. Agricultural and Food Science, 22, 223-234. https://doi. org/10.23986/afsci.7897

Park, Y., \& Runkle, E.S. (2017). Far-red radiation promotes growth of seedlings by increasing leaf expansion and whole-plant net assimilation. Environmental and Experimental Botany, 136, 41-49. https://doi.org/10.1016/j.envexpbot.2016.12.013

Park, Y., \& Runkle, E.S. (2019). Blue radiation attenuates the effects of the red to far-red ratio on extension growth but not on flowering. Environmental and Experimental Botany, 168, 103871. https://doi.org/10.1016/j.envexpbot.2019.103871

Parks, B.M., Quail, P.H., \& Hangarter, R.P. (1996). Phytochrome A regulates red light induction of phototropic enhancement in Arabidopsis. Plant Physiology, 110, 155-162.

Patel, D., Basu, M., Hayes, S., Majlath, I., Hetherington, F.M., Tschaplinski, T.J., \& Franklin, K.A. (2013). Temperaturedependent shade avoidance involves the receptor-like kinase ERECTA. The Plant Journal, 73, 980-992. https://doi. org/10.1111/tpj.12088

Pinho, P., Jokinen, K., \& Halonen, L. (2017). The influence of the LED light spectrum on the growth and nutrient uptake of hydroponically grown lettuce. Lighting Reearch \& Technology, 49(7), 866-881. https://doi. org/10.1177\%2F1477153516642269

Rajapakse, N.C., Young, R.E., McMahon, M.J., \& Oi, R. (1999). Plant height control by photoselective filters: current status and future prospects. Hort Technology, 9(4), 618-624. https://doi.org/10.21273/HORTTECH.9.4.618

Roberts, M.R., \& Paul, N.D. (2006). Seduced by the dark side: integrating molecular and ecological perspectives on the influence of light on plant defence against pests and pathogens. New Phytologist, 170, 677-699. https://doi. org/10.1111/j.1469-8137.2006.01707.x

Runkle, E. S. (2013). Manipulating light quality to elicit desirable plant growth and flowering responses. IFAC Proceedings Volumes, 46(4), 196-200. https://doi. org/10.3182/20130327-3-JP-3017.00044

Runkle, E.S., \& Heins, R.D. (2001). Specific Functions of red, far red, and blue light in flowering and stem extension of long-day plants. Journal of the American Socety for Horticultural Science, 126(3), 275-282. https://doi.org/10.21273/ JASHS.126.3.275

Sadras, V. O., Hall, A. J., Trapani, N., \& Vilella, F. (1989). Dynamics of rooting and root-length: leaf-area relationships as affected by plant population in sunflower crops. Field Crops Research, 22, 45-57. https://doi.org/10.1016/03784290(89)90088-9

Sánchez-Lamas, M., Lorenzo, C.D., \& Cerdán, P.D. (2016). Bottom-up assembly of the phytochrome network. PLOS Genetics, 12 (11), e1006413. https://dx.doi. org/10.1371\%2Fjournal.pgen.1006413

Shibuya, T., Endo, R., Kitaya, Y., \& Hayashi, S. (2016). Growth analysis and photosynthesis measurements of cucumber seedlings grown under light with different red to far-red ratios. HortScience, 51(7), 843-846. https://doi.org/10.21273/ HORTSCI.51.7.843

Shibuya, T., Itagaki, K., Tojo, M., Endo, R., \& Kitaya, Y. (2011). Fluorescent illumination with high red-to-far-red ratio improves resistance of cucumber seedlings to powdery mildew. HortScience, 46(3), 429-431. https://doi.org/10.21273/ HORTSCI.46.3.429

Singh, D., Basu, C., Meinhardt-Wollweber, M., \& Roth, B. (2015). LEDs for energy efficient greenhouse lighting. Renewable and Sustainable Energy Reviews, 49, 139-147. https://doi.org/10.1016/j.rser.2015.04.117

Srikanth, A., \& Schmid, M. (2011). Regulation of flowering time: all roads lead to Rome. Cellular and Molecular Life Sciences, 68, 2013-2037. https://doi.org/10.1007/s00018011-0673-y

Stutte, G.W., Edney, S., \& Skerritt, T. (2009). Photoregulation of bioprotectant content of red leaf lettuce with light-emitting diodes. HortScience, 44(1), 79-82. https://doi.org/10.21273/ HORTSCI.44.1.79

Suzuki, A., Suriyagoda, L., Shigeyama, T. et al. (2011). Lotus japonicus nodulation is photomorphogenetically controlled by sensing the red/far red (R/FR) ratio through jasmonic acid (JA) signalling. Proceedings of the National Academy of Sciences of the United States of America, 108, 1683716842. http://www.pnas.org/lookup/suppl/doi:10.1073/ pnas.1105892108/-/DCSupplemental

Taiz, L., \& Zeiger, E. (2014). Plant physiology. Sunderland, MA: Sinauer Associates Inc.

Thiele, A., Herold, M., Lenk, I., Quail, P.H., \& Gatz, C. (1999). Heterologous expression of Arabidopsis phytochrome B in transgenic potato influences photosynthetic performance and tuber development. Plant Physiology, 120, 73-82. https://doi.org/10.1104/pp.120.1.73

Tokuhisa, J.G., Daniels, S.M., \& Quail, P.H. (1985). Phytochrome in green tissue: Spectral and immunochemical evidence for two distinct molecular species of phytochrome in lightgrown Avena sativa L. Planta, 164, 321-332. https://doi. org/10.1007/BF00402943

Turnbull, M.H., \& Yates, D.J. (1993). Seasonal variation in the red/far-red ratio and photon flux density in an Australian sub-tropical rainforest. Agricultural and Forest Meteorology, 64(1-2), 111-127. https://doi.org/10.1016/01681923(93)90096-Z

Viczián, A., Klose, C., Adam, E., \& Nagy, F. (2017). New insights of red light-induced development. Plant, Cell \& Environment, 40, 2457-2468. https://doi.org/10.1111/pce.12880

Viršilè, A., Olle, M., \& Duchovskis, P. (2017). "LED lighting in horticulture" in Light Emitting Diodes for Agriculture. ed. S.D. Gupta. (Singapore: Springer), 113-147.

Yang, F., Feng, L., Liu, Q., et al. (2018). Effect of interactions between light intensity and red-to far-red ratio on the photosynthesis of soybean leaves under shade condition. Environmental and Experimental Botany, 150, 79-87. https:// doi.org/10.1016/j.envexpbot.2018.03.008

Yang, Z., Kubota, C., Chia, P., \& Kacira, M. (2012). Effect of endof-day far-red light from a movable LED fixture on squash rootstock hypocotyl elongation. Scientia Horticulturae, 136, 81-86. https://doi.org/10.1016/j.scienta.2011.12.023 
Yeh, N., \& Chung, J.-P. (2009). High-brightness Leds-Energy efficient lighting sources and their potential in indoor plant cultivation. Renewable and Sustainable Energy Reviews, 13, 2175-2180. https://doi.org/10.1016/j.rser.2009.01.027

Zahedi, S.M., \& Sarikhani, H. (2016). Effect of far-red light, temperature, and plant age on morphological changes and induction of flowering of a 'June-bearing' strawberry. Horticulture, Environment and Biotechnology, 57(4), 340-347. https://doi.org/10.1007/s13580-016-0018-8

Zhang, M., \& Runkle, E.S. (2019). Regulating flowering and extension growth of Poinsettia using red and far-red lightemitting diodes for end-of-day lighting. HortScience, 54(2), 323-327. https://doi.org/10.21273/HORTSCI13630-18

Zhang, M., Wogyhitman, C.M., \& Runkle, E.S. (2019a). Manipulating growth, colour, and taste attributes of fresh cut lettuce by greenhouse supplemental lighting. Scientia Horticulturae, 252, 274-282. https://doi.org/10.1016/j.scienta.2019.03.051

Zhang, Y., Zhang, Yu., Yang, Q., \& Tao, L. (2019b). Overhead supplemental far-red light stimulates tomato growth un- der intra-canopy lighting with LEDs. Journal of Integrative Agricultre, 17, 62-69. https://doi.org/10.1016/S20953119(18)62130-6

Zhen, S., \& Bugbee, B. (2019). Far-red photons are necessary for efficient photosynthesis: whole-canopy photosynthesis and radiation capture. HortScience, 54(9), S178. https://doi. org/10.1111/pce. 13730

Zhen, S., \& van Iersel, M.W. (2017). Far-red light is needed for efficient photochemistry and photosynthesis. Journal of Plant Physiology, 209, 115-122. https://doi.org/10.1016/j. jplph.2016.12.004

Zhen, S., Haidekker, M., \& van Iersel, M.W. (2019). Far-red light enhances photochemical efficiency in a wavelengthdependent manner. Physiologia plantarum, 167(1), 21-33. https://doi.org/10.1111/ppl.12834

Zou, J., Zhang, Y., Zhang, Yu., Bian, Z., Fanourakis, D., Yang, Q., \& Li, T. (2019). Morphological and physiological properties of indoor cultivated lettuce in response to additional far-red light. Scientia Horticulturae, 257, 108725. https:// dx.doi.org/10.1016/j.scienta.2019.108725 